Scientia Marina 71(1)

March 2007, 197-205, Barcelona (Spain)

ISSN: 0214-8358

\title{
Artificial collection and early growth of spat of the scallop Argopecten purpuratus (Lamarck, 1819), in La Rinconada Marine Reserve, Antofagasta, Chile
}

\author{
MIGUEL AVENDAÑO D. ${ }^{1}$, MARCELA CANTILLÁNEZ S. ${ }^{1}$, GÉRARD THOUZEAU $^{2}$ \\ and JUAN B. PENA ${ }^{3}$ \\ ${ }^{1}$ Laboratorio de Cultivo y Manejo de Moluscos, Facultad de Recursos del Mar, Universidad de Antofagasta, \\ Av. Universidad de Chile S/N, Casilla 170 Antofagasta, Chile.E-mail: mavendano@uantof.cl \\ ${ }^{2}$ Institut Universitaire Européen de la Mer, UMR 6539 CNRS, Technopôle Brest-Iroise, Place Nicolas Copernic, \\ 29280 Plouzané, France. \\ ${ }^{3}$ Instituto de Acuicultura de Torre la Sal (CSIC), E-12595 Ribera de Cabanes, Castellón, Spain.
}

\begin{abstract}
SUMMARY: Artificial collection of early juveniles ("spat") of the scallop Argopecten purpuratus in Japanese-type collectors was evaluated between January 2001 and July 2002 in the La Rinconada Marine Reserve, Antofagasta, Chile. This area of Antofagasta Bay has in the past been noted for the retention of scallop larvae by local gyres, in which their numbers can vary between 89 and 34175 larvae $\mathrm{m}^{-3}$, producing larval sets of 400 to 15340 post-larvae (spat) per collector. The results showed no quantitative relationship between larval abundance in the water and the spat density collected per day in the collectors, although high settlement rates were associated with high numbers of umboned larvae in the water. Allowing collectors to remain in situ for extended periods of 88 and 159 days resulted in a severe loss of seed which had settled in the collectors during the first 28 to 40 days of immersion. These losses varied between 50.9 and $99.6 \%$ of the spat collected, and were more prejudicial for the smaller cohorts that had settled in the collectors at the end of the first immersion period. The growth rates measured among different cohorts for each immersion period varied between 81.3 and $235.2 \mu \mathrm{m} /$ day for the first cohort $\left(\mathrm{C}_{1}\right)$ and between 64.0 and $167.4 \mu \mathrm{m}$ /day for the second cohort $\left(\mathrm{C}_{2}\right)$. The highest growth rates occurred in collectors containing the lowest numbers of spat after the occurrence of spat losses during the long periods of immersion. Occurrence of intraspecific competition within the collectors is discussed as potentially responsible for the decreases in spat numbers and the variations observed in their growth rates.
\end{abstract}

Keywords: Argopecten purpuratus, larvae, spat collection, growth, survival, Chile.

RESUMEN: CAPTACIÓN ARTIFICIAL Y CRECIMIENTO TEMPRANO DE LA "SEMILlA" DE ARGOPECTEN PURPURATUS (LAMARCK, 1819) En la Reserva Marina La Rinconada, Antofagasta, Chile. - Un programa mensual de captación de A. purpuratus, implementado en la reserva marina de La Rinconada, entre enero de 2001 y julio de 2002, la caracterizó como zona de retención larvaria, con densidades variando entre 89 y 34175 larvas $\mathrm{m}^{-3}$, y de fijaciones entre 400 y 15340 post-larvas por colector. No se encontró una relación directa entre abundancia larvaria y asentamiento, sin embargo, las mayores captaciones estuvieron asociadas a la presencia de un elevado número de estados umbonados. La mantenimiento prolongado de colectores in situ, por periodos que variaron entre 88 y 159 días, provocó una fuerte reducción en el número de semillas que se asentaron en ellos durante los primeros 28 a 40 días de inmersión Estas reducciones variaron entre el 99.6 y el $50.9 \%$ de la semilla fijada, siendo las más perjudicadas las cohortes más pequeñas, asentadas al final del primer periodo de inmersión. Las tasas de crecimiento registradas en estas cohortes, para cada periodo de inmersión, variaron entre 81.3 y $235.2 \mu \mathrm{m} /$ día para las cohortes $\mathrm{C}_{1}$ y entre 64.0 y $167.4 \mu \mathrm{m}$ /día para las cohortes $\mathrm{C}_{2}$. Las mayores tasas están directamente relacionadas con un menor número de semilla recuperada. Se discuten las competencias intraespecíficas ocurridas en los colectores, como responsables de la disminución del número de semilla y de las variaciones registradas en sus tasas de crecimiento.

Palabras clave: Argopecten purpuratus, larvas, captación de semilla, crecimiento, supervivencia, Chile. 


\section{INTRODUCTION}

One of the main beds of the scallop Argopecten purpuratus on the Chilean coast is located at the northern end of Antofagasta Bay (La Rinconada) in northern Chile at $23^{\circ} 28^{\prime} \mathrm{S} ; 7^{\circ} 30^{\prime} \mathrm{W}$. This bed, occupying an area of about 270 ha, has become extremely important in basic and applied research on this scallop, and was protected by the establishment of the La Rinconada Marine Reserve by Supreme Decree $\mathrm{N}^{\circ}$ 522 of the Chilean government in September 1997. Previous fieldwork on this bed found it to be naturally divisible into two zones, including a central, densely populated $\left(\sim 11\right.$ ind. $\left.\mathrm{m}^{-2}\right)$ portion, and a peripheral portion with lower densities averaging about three individuals per $\mathrm{m}^{2}$ (Cantillánez et al., 2001; Avendaño and Cantillánez, 1997, 2005).

The Reserve is intermittently exposed to coastal upwelling processes throughout the year, with frequencies of 0.2 to 0.4 cycles per day during the most intense periods. The irregular occurrence of this phenomenon in the area often punctuates normal seasonal cycles occurring in the ocean. This may include abrupt temperature changes in the water column from one day to the next of a magnitude equal to an entire seasonal variation, ie. up to $6.5^{\circ} \mathrm{C}$ within a 24-hour period (Guillen, 1983; Rodríguez et al., 1991; Marín et al., 1993; Escribano et al., 1995; Cantillánez, 2000; Avendaño et al., 2004). Coastal upwelling processes produce phytoplankton peaks throughout the year, with values for chlorophyll $a$ varying from a minimum of $0.6 \mu \mathrm{g} \mathrm{l}^{-1}$ to a maximum of $24.8 \mu \mathrm{g} \mathrm{l}^{-1}$ (Rodríguez et al., 1991; Cantillánez, 2000; Avendaño et al., 2004).

An interesting characteristic of the A. purpuratus population in the Reserve is its intense reproductive activity, which occurs from September to April (Avendaño, 1993; Avendaño and Le Pennec, 1996; 1997; Cantillánez, 2000; Cantillánez et al., 2005). This reproductive process generates a continuous presence in the area of larvae of this species, whose periods of greatest abundance are directly related to the periods of the highest reproductive activity (Cantillánez, 2000; Cantillánez et al., 2001; Avendaño et al., 2006). The continuous presence of these larvae in the plankton of the Reserve is due to the presence of current gyres in the area which lead to a high capacity for retention of particulate matter within an area about $5 \mathrm{~km}$ in diameter, favouring continuous natural settlement of postlarvae on the bottom and/or into artificial collectors placed in the environment (Cantillánez, 2000; Cantillánez et al., 2001; Avendaño and Cantillánez, 2005; Avendaño et al., 2006).

One of the primary objectives in the creation of the Reserve was the implementation of programmes for the artificial collection of juvenile scallops ("spat") for supplying at least part of the demand for juvenile scallops by the developing Chilean scallop culture industry. This industry, based on Japanese aquaculture technology, has to date been supplied with juvenile scallops collected from natural beds by divers. The limited numbers of these juveniles represents a bottleneck for this culture since they are only sporadically available due to interannual variations in the population. Scallop spat is also required for repopulation of over-exploited natural beds, which have recently been converted to Management Areas for the benefit of artisanal fishers under provisions of the Chilean Law of Fisheries and Aquaculture.

This study presents data related to the larval cycle and settlement of postlarval scallops in artificial collectors, as well as the growth and recovery of the spat maintained in the collectors at sea for extended periods of time. The objective of the study was to explore efficient methods of spat production for use in mass scallop culture and repopulation efforts, based on fundamental knowledge of the resource gained from comprehensive experimentation in the field.

\section{METHODOLOGY}

\section{Larval sampling}

Quantitative larval samples were obtained every two weeks between January 2001 and May 2002 at a single station within the Reserve known to be a site of high settlement (Fig. 1). The sampling station was within the zone of small internal gyres intermingled with inertial zones within the reserve. The gyres served to maintain larvae and other particulate matter in suspension, while sedimentation took place normally in the inertial zones (Avendaño and Cantillánez, 1996; Cantillánez, 2000; Avendaño et $a l ., 2004)$. The samples were obtained by making vertical plankton hauls through the entire water column (17 m depth) using a conical plankton net with $53 \mu \mathrm{m}$ mesh openings. Each sample was fixed in $70 \% \mathrm{EtOH}$, and upon transport to the laboratory it 


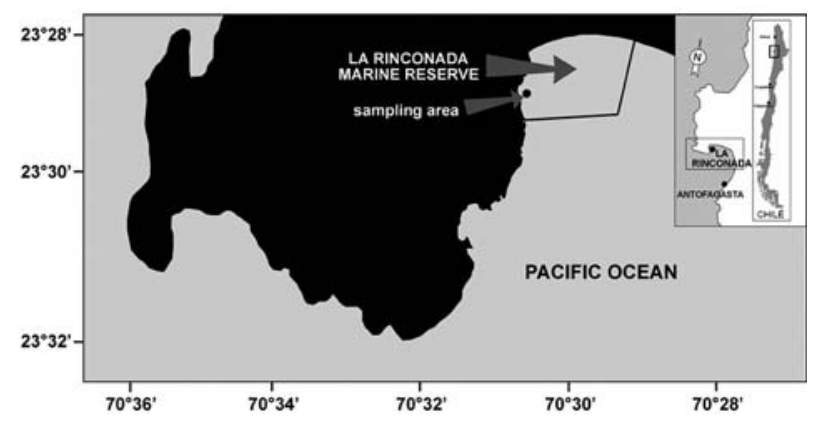

FIG. 1. - Geographic location of the study area at the La Rinconada Marine Reserve, Antofagasta Chile.

was mixed in a ten-division plankton splitter. Scallop larvae in two of the 1/10 fractions of each sample were counted and measured for antero-posterior length in a stereoscopic microscope (Le Pennec, 1978; Salaün, 1994). The total number of larvae in the sample was calculated from the two samples counted, and the density of larvae per cubic metre of seawater was determined from the amount of water passing through the plankton net per haul.

Counts of larvae in the samples were separated into early forms (veliger larvae) of less than $170 \mu \mathrm{m}$ in length, and advanced forms (umboned and pediveliger larvae) of $>170 \mu \mathrm{m}$ which were approaching, or had reached, competence for settlement. Advanced larvae had a completely developed set of hinge teeth, which was a character that did not change until they passed metamorphosis (Avendaño, 1993).

\section{Spat collection}

The relation between the presence of larvae and settlement of larval cohorts was determined by placing experimental scallop spat collectors near the larvae collection station. From January 2001 to July 2002, sets of three Japanese-type "onion bag" spat collectors were hung from a longline installed one metre above the bottom (16 $\mathrm{m}$ depth) (following Thouzeau, 1991a) for periods of 21 to 49 days per group. The collectors were recovered by a diver, and each collector was placed in a protective bag for transport to the laboratory. The contents of each collector were washed free using seawater, and screened on a $180 \mu \mathrm{m}$ mesh-opening nylon screen to retain all postlarvae and juvenile scallops. The spat thus obtained was well mixed in seawater and placed in the plankton splitter (as above), with two subsamples taken for counting and measuring; measurements were made using a stereoscopic microscope fitted with an ocular micrometer. The total numbers of spat obtained in each collector was calculated from the two subsamples from each of the three collectors. Four series of three additional collectors were emplaced in January, October, and December 2001, and also in March 2002, representing the periods of most intense reproductive activity in the scallop bed (Cantillánez et al., 2005). These were recovered after 88 or 159 days in situ in order to determine the effects on the settled scallops of extended residence in the collector bags at the collection site. Settled scallops were recovered from all the collectors as described above, and were individually counted and measured. All specimens exceeding the width of the ocular micrometer scale were measured using an electronic caliper accurate to $0.01 \mathrm{~mm}$.

The population structure of the spat from the collectors was submitted to a cohort analysis using the MIX 3.1a program (MacDonald and Pitcher, 1979) in order to identify the numbers of micro-cohorts settled during the immersion period of each collector, and the mean size of spat in each cohort. The size-frequency histograms were plotted along a normal distribution (significance level $=0.05$ ). The mean sizes of the spat in the cohorts obtained from the series of collectors allowed to remain in situ for extended periods enabled the apparent daily growth rates of each cohort during the immersion period to be calculated, using the following relation, assuming that the post-larval growth was linear, according to Thouzeau (1989) and Cantillánez (2000):

\section{Apparent daily growth rate $(\mu \mathrm{m} /$ day $)=$}

$$
=\frac{\text { Final mean size }(\mu \mathrm{m})-\text { Initial mean size }(\mu \mathrm{m})}{\text { Date immersion }- \text { Date recovery }\left(\mathrm{n}^{\mathrm{o}} \text { days }\right)}
$$

The study was divided arbitrarily into 15 experimental spat collection periods (Table 1), during which up to three larval samples were taken (Table 2 ) in order to establish a relation between the presence of larvae in the water $\left(\mathrm{nm}^{-3}\right)$ and postlarval settlement in the collectors. The average availability of larvae in the water $\left(\mathrm{n} \mathrm{m}^{-3}\right)$ was calculated at the end of each experimental collection period. The average number of postlarvae obtained per period was converted to the number of scallops per collector, per day in situ (n collector ${ }^{-1}$ day $\left.^{-1}\right)$. We then determined the relation between larval density $\left(\mathrm{nm}^{-3}\right)$ and scallops per collector (n collector ${ }^{-1}$ day $^{-1}$ ) by applying regression analyses for the following statistical models: 
TABLE 1. - Settlement of Argopecten purpuratus spat on artificial collectors in La Rinconada Marine Reserve from January 2001 to May 2002 $(\mathrm{sd}=$ standard desviation $)$.

\begin{tabular}{|c|c|c|c|c|c|}
\hline $\begin{array}{l}\text { Dates } \\
\text { Installation-recovery }\end{array}$ & $\begin{array}{l}\text { immersion } \\
\text { time (days) }\end{array}$ & $\begin{array}{l}\text { mean spat per } \\
\text { collector } \pm \text { sd }\end{array}$ & $\begin{array}{c}\text { cohort } 1 \\
\text { length } \pm \mathrm{sd}(\mu \mathrm{m})\end{array}$ & $\begin{array}{c}\text { cohort } 2 \\
\text { length } \pm \mathrm{sd}(\mu \mathrm{m})\end{array}$ & $\begin{array}{c}\text { cohort } 3 \\
\text { length } \pm \mathrm{sd}(\mu \mathrm{m})\end{array}$ \\
\hline 06/01/01 - 03/02/01 & 28 & $12883 \pm 896$ & $940 \pm 290$ & $530 \pm 110$ & -- \\
\hline $03 / 02 / 01-03 / 03 / 01$ & 28 & $14153 \pm 2725$ & $633 \pm 138$ & -- & -- \\
\hline $03 / 03 / 01-06 / 04 / 01$ & 34 & $4370 \pm 466$ & $877 \pm 173$ & -- & -- \\
\hline $06 / 04 / 01-06 / 05 / 01$ & 30 & $1170 \pm 197$ & $702 \pm 160$ & -- & -- \\
\hline $06 / 05 / 01-08 / 06 / 01$ & 33 & $878 \pm 137$ & $1618 \pm 272$ & $841 \pm 223$ & -- \\
\hline $08 / 06 / 01-06 / 07 / 01$ & 28 & $1450 \pm 473$ & $1125 \pm 158$ & $532 \pm 112$ & -- \\
\hline $06 / 07 / 01-09 / 08 / 01$ & 34 & $72 \pm 31$ & $502 \pm 116$ & -1 & -- \\
\hline $09 / 08 / 01-14 / 09 / 01$ & 36 & $798 \pm 101$ & $458 \pm 166$ & -- & -- \\
\hline $14 / 09 / 01-05 / 10 / 01$ & 21 & $200 \pm 28$ & $1067 \pm 133$ & -- & -- \\
\hline $06 / 10 / 01-15 / 11 / 01$ & 40 & $15340 \pm 2786$ & $3200 \pm 290$ & $1740 \pm 280$ & $700 \pm 170$ \\
\hline $15 / 11 / 01-08 / 12 / 01$ & 23 & $890 \pm 71$ & $880 \pm 250$ & -1 & -- \\
\hline $08 / 12 / 01-08 / 01 / 02$ & 31 & $4270 \pm 622$ & $863 \pm 242$ & $410 \pm 78$ & -- \\
\hline $10 / 01 / 02-28 / 02 / 02$ & 49 & $1860 \pm 339$ & $1670 \pm 290$ & $360 \pm 130$ & -- \\
\hline $28 / 02 / 02-13 / 04 / 02$ & 44 & $5300 \pm 481$ & $1879 \pm 1213$ & $819 \pm 135$ & $468 \pm 45$ \\
\hline $07 / 04 / 02-14 / 05 / 02$ & 37 & $400 \pm 35$ & $1680 \pm 360$ & -- & -- \\
\hline
\end{tabular}

$$
\begin{gathered}
y=b_{0}+b_{1} x+e \text { (linear regression) } \\
y=b_{0}+b_{1} x+b_{2} x^{2}+e
\end{gathered}
$$

(second order polynomial regression)

where :

$y=$ response variable: spat density per day (n collector $^{-1}$ day $^{-1}$ )

$x=$ independent variable: larval density $\left(\mathrm{nm}^{-3}\right)$

$b_{0}=\mathrm{y}$ intercept

$b_{1}$ and $b_{2}=$ coefficients of linear and quadratic regression, respectively.

The models were fitted using the GLM procedure (General Linear Model, using least-square fitting protocols) in the SAS Version 6.12 (Statistical Analysis System, 1996). The null hypothesis applied for both statistical models was the non-existence of either a linear $\left(b_{1}=0\right)$ or a quadratic $\left(b_{2}=0\right)$ relation between the response and independent variables.

\section{Water temperature}

Bottom water temperature was measured using data loggers (VEMCO, model TR) installed at a depth of $16 \mathrm{~m}$, recording the temperature every six hours during the entire collection period.

\section{RESULTS}

\section{Larval samples}

Scallop larvae were continuously present in the water column throughout the study (Table 2), with densities exceeding 1000 larvae $\mathrm{m}^{-3}$ between January and the beginning of June 2001 (except

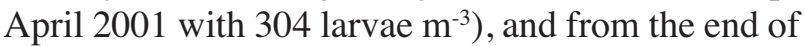
September 2001 to the beginning of April 2002. The highest numbers observed occurred in May and December 2001 and in March 2002, with values of 34175,21700 and 29802 larvae $\mathrm{m}^{-3}$ respectively. High percentages of umbo larvae (length $>170 \mu \mathrm{m}$ ) were present in most of the samples.

\section{Spat collection}

Settlement of postlarvae of A. purpuratus was continuous in the Reserve from January 2001 to May 2002. During this period, settlements of one to three micro-cohorts of scallops were recorded, with mean sizes ranging from 360 to $3200 \mu \mathrm{m}$. The maximum average settlement occurred between October and April. Table 1 shows the periods of immersion of the collectors, the numbers of spat, and the microcohorts (with their mean size) that settled in each collector. No association was observed between scallop density collected per day and larval density. Neither the linear model $(\mathrm{P}=0.871 ; \mathrm{y}=137.8-$ $0.0009 \mathrm{x} ; \mathrm{r}=0.046)$ nor the quadratic model $(\mathrm{P}=$ $\left.0.471 ; y=75.4+0.0188 x-0.000001 x^{2} ; r=0.17\right)$ gave significant correlations of the data. This result suggested that the abundance of settled scallops cannot be predicted from the abundance of larvae in the plankton.

The results obtained from series of collectors placed in situ for 88 to 159 days, which were tested in parallel with the first sets that remained installed for 28 and 40 days, are given in Table 3. In the first set, two cohorts settled into collectors that were 
TABLE 2. - Larval density $\left(\mathrm{n}^{\circ}\right.$ of larvae $\left.\mathrm{m}^{-3}\right)$, size range, mean, and percentage of umbo larvae of $A$. purpuratus found in samplings carried out within La Rinconada Marine Reserve between January 2001 and May 2002

\begin{tabular}{|c|c|c|c|c|}
\hline Date & $\begin{array}{c}n \text { of } \\
\text { larvae } \mathrm{m}^{-3}\end{array}$ & $\begin{array}{l}\text { size range } \\
\quad(\mu \mathrm{m})\end{array}$ & $\begin{array}{l}\text { mean length } \\
\qquad(\mu \mathrm{m})\end{array}$ & $\begin{array}{c}\% \text { larvae } \\
>170 \mu \mathrm{m}\end{array}$ \\
\hline 06/01/01 & 2143 & $105-220$ & $162.0 \pm 40.9$ & 44 \\
\hline $20 / 01 / 01$ & 3393 & $100-220$ & $168.0 \pm 33.6$ & 50 \\
\hline $03 / 02 / 01$ & 5090 & $101-242$ & $187.0 \pm 50.8$ & 72 \\
\hline $03 / 03 / 01$ & 8073 & $101-227$ & $176.0 \pm 40.6$ & 60 \\
\hline $18 / 03 / 01$ & 14073 & $106-248$ & $188.1 \pm 35.8$ & 75 \\
\hline $25 / 03 / 01$ & 5635 & $121-248$ & $169.1 \pm 23.2$ & 46 \\
\hline $06 / 04 / 01$ & 304 & $106-253$ & $165.3 \pm 35.6$ & 47 \\
\hline $06 / 05 / 01$ & 34175 & $121-253$ & $193.5 \pm 34.1$ & 74 \\
\hline $08 / 06 / 01$ & 4920 & $136-277$ & $184.4 \pm 30.6$ & 64 \\
\hline $06 / 07 / 01$ & 98 & $106-212$ & $184.3 \pm 30.9$ & 76 \\
\hline $26 / 07 / 01$ & 168 & $151-252$ & $201.7 \pm 27.2$ & 69 \\
\hline $10 / 08 / 01$ & 89 & $101-212$ & $141.9 \pm 47.9$ & 42 \\
\hline $14 / 09 / 01$ & 598 & $101-252$ & $181.1 \pm 35.8$ & 79 \\
\hline $21 / 09 / 01$ & 1357 & $111-202$ & $151.6 \pm 25.2$ & 20 \\
\hline $05 / 10 / 01$ & 7001 & $141-247$ & $189.7 \pm 23.7$ & 91 \\
\hline $18 / 10 / 01$ & 9573 & $101-212$ & $147.9 \pm 27.3$ & 40 \\
\hline $25 / 10 / 01$ & 2152 & $101-222$ & $160.1 \pm 36.9$ & 45 \\
\hline $15 / 11 / 01$ & 5680 & $101-222$ & $175.6 \pm 29.2$ & 59 \\
\hline $06 / 12 / 01$ & 4095 & $101-212$ & $117.7 \pm 33.4$ & 11 \\
\hline $13 / 12 / 01$ & 21700 & $101-253$ & $137.8 \pm 41.9$ & 15 \\
\hline $08 / 01 / 02$ & 8197 & $101-237$ & $181.4 \pm 35.6$ & 61 \\
\hline $19 / 01 / 02$ & 1009 & $101-217$ & $167.2 \pm 29.2$ & 51 \\
\hline $28 / 02 / 02$ & 2232 & $161-232$ & $186.1 \pm 29.5$ & 72 \\
\hline $15 / 03 / 02$ & 29802 & $101-222$ & $166.5 \pm 43.3$ & 53 \\
\hline $05 / 04 / 02$ & 1241 & $131-217$ & $176.1 \pm 26.0$ & 59 \\
\hline $13 / 04 / 02$ & 761 & $121-222$ & $187.4 \pm 34.1$ & 60 \\
\hline $18 / 05 / 02$ & 330 & $101-212$ & $163.5 \pm 37.7$ & 43 \\
\hline
\end{tabular}

installed for 28 days, forming an average catch of 12883 spat per collector. In contrast, the series of collectors that remained in place for 88 days had a settlement of two additional cohorts $\left(\mathrm{C}_{3}\right.$ and $\left.\mathrm{C}_{4}\right)$, along with the first two cohorts (Table 3). During this period, cohorts $\mathrm{C}_{1}$ and $\mathrm{C}_{2}$, decreased to 19.9 and $46.9 \%$ of their original numbers, and had growth rates of 92 and $64 \mu \mathrm{m} /$ day, respectively. There was a strong decrease in the percentage recovery of cohorts which had settled during the first immersion period in collectors that had remained in place for longer periods, with the lowest recovery of the initial cohorts in the 159-day immersion trial (second series). Here, cohorts $\mathrm{C}_{1}, \mathrm{C}_{2}$ and $\mathrm{C}_{3}$ (Table 3 ), which added up to a total of 15340 spat that settled during the first immersion period, decreased to $13.7,13.8$, and $0.4 \%$ of their original numbers, respectively. Their apparent daily growth rates were 178.6, 136.2 and $65.2 \mu \mathrm{m} /$ day, respectively (Table 3 ). Our analysis identified only one cohort in collectors that remained immersed for 115 days (third series), compared with the two cohorts identified during the initial immersion period of 31 days, in which the total number of spat was 4280 . This cohort dropped to $49.1 \%$ of its initial number, and showed a growth

TABLE 3. - Numbers and size (shell length; mm) of Argopecten purpuratus spat captured for each group of the Japanese-type collector bags suspended at $16 \mathrm{~m}$ depth for two successive periods in 2001-2002 in La Rinconada Marine Reserve, Antofagasta (Chile).

\begin{tabular}{|c|c|c|c|c|c|c|c|}
\hline Group \# & Cohort \# & $\begin{array}{l}\text { Inmersion } \\
\text { time (days) }\end{array}$ & $\begin{array}{c}\text { Dates } \\
\text { Installation-recovery }\end{array}$ & Abundance & \multicolumn{2}{|c|}{ Mean values per collector $(n=3)$} & $\begin{array}{l}\text { Apparent daily } \\
\text { growth rate }(\mu \mathrm{m}\end{array}$ \\
\hline \multirow[t]{3}{*}{1} & $\mathrm{C}_{1}$ & 28 & 06/01/01-03/02/01 & $3504 \pm 243$ & 27.2 & $0.94 \pm 0.29$ & \\
\hline & $\mathrm{C}_{2}$ & & & $9379 \pm 652$ & 72.8 & $0.53 \pm 0.11$ & \\
\hline & Total & & & $12883 \pm 896$ & & & \\
\hline \multirow[t]{5}{*}{1} & $\mathrm{C}_{1}$ & 88 & 06/01/01-04/04/01 & $689 \pm 105$ & 6.1 & $6.46 \pm 1.70$ & 92 \\
\hline & $\mathrm{C}_{2}$ & & & $4397 \pm 671$ & 38.9 & $4.37 \pm 0.98$ & 64 \\
\hline & $\mathrm{C}_{3}^{2}$ & & & $2735 \pm 418$ & 24.2 & $2.44 \pm 0.52$ & 39 \\
\hline & $\mathrm{C}_{4}$ & & & $3481 \pm 532$ & 30.8 & $1.07 \pm 0.33$ & 12.8 \\
\hline & Total & & & $11302 \pm 1726$ & & & \\
\hline \multirow[t]{4}{*}{2} & $\mathrm{C}_{1}$ & 40 & $06 / 10 / 01-15 / 11 / 01$ & $2730 \pm 496$ & 17.8 & $3.20 \pm 0.29$ & \\
\hline & $\mathrm{C}_{2}$ & & & $3099 \pm 563$ & 20.2 & $1.74 \pm 0.28$ & \\
\hline & $\mathrm{C}_{3}^{2}$ & & & $9511 \pm 1727$ & 62.0 & $0.70 \pm 0.17$ & \\
\hline & Total & & & $15340 \pm 2786$ & & & \\
\hline \multirow[t]{4}{*}{2} & $\mathrm{C}_{1}$ & 159 & 06/10/01-14/03/02 & $375 \pm 175$ & 44.8 & $24.45 \pm 4.45$ & 178.6 \\
\hline & $\mathrm{C}_{2}$ & & & $427 \pm 199$ & 51.0 & $17.95 \pm 3.60$ & 136.2 \\
\hline & $\mathrm{C}_{3}^{2}$ & & & $35 \pm 16$ & 4.2 & $8.46 \pm 2.23$ & 65.2 \\
\hline & Total & & & $837 \pm 390$ & & & \\
\hline \multirow[t]{3}{*}{3} & $\mathrm{C}_{1}$ & 31 & 08/12/01-08/01/02 & $2828 \pm 411$ & 66.1 & $0.84 \pm 0.24$ & \\
\hline & $\mathrm{C}_{2}$ & & & $1452 \pm 211$ & 33.9 & $0.40 \pm 0.24$ & \\
\hline & Total & & & $4270 \pm 622$ & & & \\
\hline \multirow[t]{2}{*}{3} & $\mathrm{C}_{1}$ & 115 & 08/12/01-02/04/02 & $2102 \pm 732$ & & $7.67 \pm 3.42$ & 81.3 \\
\hline & Total & & & $2102 \pm 732$ & & & \\
\hline \multirow[t]{3}{*}{4} & $\mathrm{C}_{1}$ & 33 & 02/03/02-04/04/02 & $1283 \pm 261$ & 34.2 & $2.85 \pm 0.56$ & \\
\hline & $\mathrm{C}_{2}$ & & & $2464 \pm 503$ & 65.8 & $1.07 \pm 0.31$ & \\
\hline & Total & & & $3747 \pm 764$ & & & \\
\hline \multirow[t]{4}{*}{4} & $\mathrm{C}_{1}$ & 127 & 02/03/02-07/07/02 & $288 \pm 47$ & 53.0 & $24.96 \pm 3.36$ & 235.2 \\
\hline & $\mathrm{C}_{2}$ & & & $192 \pm 31$ & 35.4 & $16.78 \pm 2.19$ & 167.4 \\
\hline & $\mathrm{C}_{3}^{2}$ & & & $63 \pm 10$ & 11.6 & $7.91 \pm 1.90$ & \\
\hline & Total & & & $543 \pm 88$ & & & \\
\hline
\end{tabular}




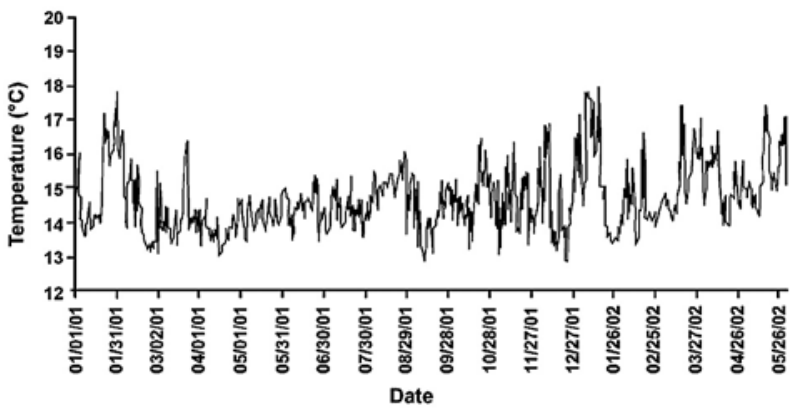

FIG. 2. - Average daily water temperature obtained at $16 \mathrm{~m}$ depth at the La Rinconada Marine Reserve, Antofagasta, Chile between January 2001 and May 2002 .

rate of $81.3 \mu \mathrm{m} /$ day (Table 3 ). In contrast to that reported for the preceding period, the fourth series of collectors, which remained immersed for 127 days, demonstrated the settlement of a new cohort compared with the two cohorts that had settled during their first 33 days in place. During this last period, cohorts $\mathrm{C}_{1}$ and $\mathrm{C}_{2}$ decreased to 22.4 and $7.8 \%$ of their original numbers, and had growth rates of 235.2 and $167.4 \mu \mathrm{m} /$ day, respectively (Table 3 ).

\section{Temperature}

The daily temperature record at $16 \mathrm{~m}$ depth, as shown in Figure 2, had a broad range of fluctuation throughout the study period, varying between $12.9^{\circ}$ and $18^{\circ} \mathrm{C}$, with both these extremes occurring in the summer months (December to March). Nevertheless, the average for each period of prolonged collector immersion varied between $14.6^{\circ} \mathrm{C}$ \pm 1.12 and $15.1^{\circ} \mathrm{C} \pm 0.94$, with the lowest temperature recorded during the first period of installation (January-April 2001), and the highest temperature in the last immersion period (March-July 2002).

\section{DISCUSSION}

The constant presence of $A$. purpuratus larvae found in the Reserve area, with high densities between October and March (and extending even to the beginning of June, as in 2001) confirmed previous results obtained at this site demonstrating the high reproductive activity of this scallop population, which intensifies between September and April (Avendaño and Le Pennec, 1996; 1997; Cantillánez, 2000; Cantillánez et al., 2005).

The predominance of larvae at or near competence to settle $(>170 \mu \mathrm{m})$ in the larval samples, together with the results observed on the settlement of spat in collectors suspended in the Reserve for the shorter time periods, reconfirmed earlier contentions that the area was a zone of $A$. purpuratus larval retention (Cantillánez, 2000; Cantillánez et al., 2001; Avendaño et al., 2006), and also indicated that the most important settlement was related to the periods of highest reproductive activity. The percentage of larvae greater than umbo size is used to predict the optimum time period for placing collector bags in the sea (Slater, 1980).

A decrease in the number of larvae in the water was observed to begin in April 2002 compared with the same period in 2001, reflected in the lower catch of spat in collectors recovered in May 2002. These reductions may have been due to the decrease in the abundance of the adult broodstock on the scallop bed, which produces the gametes supporting its reproductive processes. The broodstock numbers on the bed, reduced by harvesting, declined from 2.6 million individuals in March 2001 to 930000 individuals in May 2002 (Avendaño et al., 2001; Avendaño and Cantillánez, 2005).

The results showing lack of correlation between scallop spat settlement in collectors in relation to the number of larvae in the water, particularly those in the large size class, were disturbing in practical terms with regard to commercial collection of spat for supplying mass cultures. The scallop culture companies incur major costs when installing hundreds or thousands of collectors in a bay based on the presence of larvae in the water, and when settlement in the collectors fails, this investment is lost. However, it should be emphasised that the methods used in the present study for calculation of seed capture per day over long periods of exposure of the collectors may not have been well associated with larval densities measured during the exposure period, especially considering that settlement of cohorts apparently occurred within short time periods.

In $P$. maximus the absence of a direct relation between the abundance of larval cohorts and yield in spat collection was described by Boucher (1985). This author suggested that the absence of settlement of many larval cohorts implied a high degree of larval mortality which was independent of larval density. Thouzeau (1989; 1991b,c; 1995), suggested that for P. maximus the abundance of post-metamorphic stages due to larval survival was mainly regulated by hydrodynamism, temperature, and trophic conditions in the environment. Nevertheless, Slater (2005), found good correlations between the num- 
bers of larvae in the water and spat settlement in $P$. maximus in some years in Mulroy Bay, Ireland.

In the present study, the existence on some occasions of a degree of proportionality between the number of umbo larvae and settlement in collectors, as with those installed between January and the beginning of July 2001 and between October 2001 and April 2002, was also previously observed for this bed by Cantillánez (2000). A correlation between the presence of umbo larvae in the water and the eventual number of spat settled in collectors was reported for Patinopecten yessoensis in Mutsu Bay, Japan, where numbers ranging from 100 to 200 larvae $\mathrm{m}^{-3}$ were associated with catches of 1000 scallop spat per collector, while 1000 larvae $\mathrm{m}^{-3}$ produced settlement values of 3-6 x 104 spat per collector (Ventilla, 1982). This success does not apply to A. purpuratus, even at densities of over $2.5 \times 10^{4}$ umbo larvae $\mathrm{m}^{-3}$.

The appearance of new cohorts settled in collectors which remained submerged for prolonged periods, as occurred in January 2001 and March 2002, supports earlier observations made in this bay by Cantillánez (2000), who noted that settlement continued in collectors which were allowed to remain submerged for extended periods of time, recognising seven cohorts settled in collectors that had remained in place for 98 days. Increasing scallop collection with extended periods of immersion of collectors has also been reported by Román and Cano (1987). In contrast to these results, however, various authors have suggested that for pectinids, including Placopecten magellanicus, P. maximus and $P$. yessoensis, extended periods of immersion of collectors only results in the biofouling of the collectors, inhibiting larval settlement and interference with the survival of settled scallops (Yamamoto, 1964; Minchin, 1976; Gruffydd and Beaumont, 1972; Gruffydd et al., 1975; Paul, 1978; Naidu and Scaplen, 1979; Brand et al., 1980; Fegan, 1983; Thouzeau, 1989; 1991a, b). Fegan (1983), suggested that biofouling of the collectors became effective in inhibiting scallop settlement after 15 days, and Wilson (1987), failed to observe settlement of $P$. maximus after one month of collector immersion. In the present study, the average sizes of the new cohorts in the collectors suggest that new settlement of cohorts is able to occur at La Rinconada only within the first 60 days of immersion.

The observation that cohorts originally settling in large numbers suffer decimation in numbers when held for prolonged periods in the collectors may be due to crowding as the scallops grow. Decreases in a given cohort can also be affected by arrival of new cohorts in collectors remaining in place for prolonged periods. Mason (1983), suggested that this phenomenon was due to intraspecific competition for space and food, inducing high mortalities, while Ventilla (1982), suggested that settlement of over 10000 spat per collector resulted in their stunted growth and low survival. This type of result was obtained in the present study in collectors maintained in situ for 88 and 115 days, from which large numbers of spat were recovered. In these collectors significant reductions in the numbers of the first cohorts that settled were caused by the arrival of new cohorts, which also led to reduced growth rates of spat belonging to the first cohorts. Reduction in apparent daily growth rate was most evident in collectors remaining in situ for 115 days, in which seed from cohort $\mathrm{C}_{1}$ had a growth rate of $81.3 \mu \mathrm{m} /$ day and numbers became reduced to $49 \%$ of those that originally settled in the initial phase of immersion of the collectors. Although two cohorts could be identified in these collectors after the first immersion period of 31 days, and then only one cohort 115 days later, this was probably due to the narrow range in mean sizes of scallops in the cohorts $\left(\mathrm{C}_{1}=840 \mu \mathrm{m}\right.$ and $\left.\mathrm{C}_{2}=400 \mu \mathrm{m}\right)$ in the early phase of the experiment. Reduction in growth has also been suggested by Narvarte (2001) for collectors containing spat of Aequipecten tehuelchus, an opinion shared by Thouzeau (1995), who stated that the simultaneous presence of postlarvae of $P$. maximus and its principal competitors in the collectors suggested the occurrence of direct spatial and trophic competition between them.

In contrast to what was stated above about reduction of growth with crowding of the collectors, the highest growth rates measured for cohorts $\mathrm{C}_{1}$ and $\mathrm{C}_{2}$ in the collectors that remained in situ for 127 and 159 days were related to the greatest reductions in the numbers of individuals that made up each of the cohorts.

Growth of the spat within the collectors at rates of $82 \mu \mathrm{m} /$ day $\left(14.7^{\circ} \mathrm{C}\right)$ and $143 \mu \mathrm{m} /$ day $\left(15.3^{\circ} \mathrm{C}\right)$ reported for this bay by Cantillánez (2000) were lower than those obtained at the same depth and immersion periods in the present study, in which the temperature varied between 14.6 and $15.1^{\circ} \mathrm{C}$. Individual scallops in cohorts $\mathrm{C}_{1}$ and $\mathrm{C}_{2}$ grew at rates of 235.2 and 167.4 $\mu \mathrm{m} /$ day, respectively, early in their immersion when they exhibited maximum growth rates. Several authors have discussed the high variations observed in the growth rates of juvenile scallops in suspended 
culture, related to temperature variations due to the depths of installation of the cultures (Gilliespie, 1983; Wallace and Reinsnes, 1984; 1985; Lodeiros et al., 2001). Thouzeau (1991b), reported a sustained decrease in postlarval growth of P. maximus in collectors, which coincided with large variations in temperature and food in the water. Minchin (1976) reported low growth rates for spat held close to the bottom. Sicard et al., (1999) also suggested that variations in temperature were responsible for variations in growth rate in Argopecten ventricosus. We suggest, however, that A. purpuratus is probably less sensitive to temperature variations than other species due to its adaptation to the often precipitous, short-term temperature changes typical of upwelling-affected areas on the Chilean coast such as the La Rinconada Reserve. Whatever external factors affect the growth and survival of spat in the collectors, it was clear to us that the scallop density in the collectors was a major factor affecting their growth rates, overshadowing even the length of time the collectors remained in situ. The highest apparent daily growth rates were related to the lower numbers of scallops in each of the cohorts during the present study (Table 3 ).

Natural factors related to catch, growth, and survival of spat in collectors has been a vital concern of workers attempting to maximise yields and size of spat in commercial spat-collection operations (Thouzeau, 1991b). Nowhere has this been more important than in Chile, where the main source for the developing scallop culture industry has been the capture of wild spat of A. purpuratus (Disalvo et al., 1984; Gajardo et al., 1996; Abarca, 2001; Stotz and Mendo, 2001), and most preferably spat measuring $15 \mathrm{~mm}$ (Narvarte et al., 2001). The present results have demonstrated the feasibility of, and provided valuable quantitative information on, artificial spat collection in the La Rinconada Marine Reserve, reaffirming the original rationale for establishment of the Reserve. We have also determined that it is not advisable to leave collectors in the sea for extended periods, which may result in losses of initially collected spat. To avoid these losses is recommendable that the spat is harvested from the collectors before completing the three months in the water. They should be selected by size and transferred at optimal densities to suspended culture, using for example "baby lantern nets" or culture trays (Maeda-Martínez et al., 1997; Avendaño et al., 2001), until they reach a size that is useful for initiating intermediate culture or for use in repopulation activities.

\section{ACKNOWLEDGEMENTS}

The present study was carried out within the framework of the FNDR project, Code BIP $\mathrm{N}^{\circ}$ 20127869-0. The authors thank Dr. Louis DiSalvo for assistance in translation, and for providing helpful comments and suggestions on the MS. We also thank Dr. Ricardo Guiñez for his aid with the statistical analyses and Dr. Alfonso Maeda-Martínez and Dr. Andrew Brand for their constructive comments and for improving the English of the MS.

\section{REFERENCES}

Abarca, A. - 2001. Scallop Hatcheries of Argopecten purpuratus (Lamarck, 1819) in Chile: A survey of the present situation. 13 ${ }^{\text {th }}$ International Pectinid Workshop, 18-24 April 2001, Coquimbo Chile, pp. 74-75.

Avendaño, M. - 1993. Données sur la biologie de Argopecten purpuratus (Lamarck, 1819), Mollusque Bivalve du Chili. Ph D. thesis Univ. Brest, France.

Avendaño, M. and M. Cantillánez. - 1996. Efecto de la pesca clandestina, sobre Argopecten purpuratus (Lamarck, 1819), en el banco de La Rinconada, II Región. Cienc. Tecnol. Mar., CONA, 19: 57-65.

Avendaño, M. and M. Cantillánez. - 1997. Necesidad de crear una reserva marina de Ostiones en el banco de la Rinconada". Estud. Oceanol., Fac. Recur. Mar. Univ. Antofagasta, 16: 109-113.

Avendaño, M. and M. Cantillánez. - 2005. Growth and demographic structure of Argopecten purpuratus (Lamarck, 1819), in the La Rinconada Marine Reserve, Antofagasta, Chile. Cienc. Mar., 31(3): 491-503.

Avendaño, M. and M. Le Pennec. - 1996. Contribución al conocimiento reproductivo de Argopecten purpuratus en dos poblaciones de la II Región - Chile. Estud. Oceanol., Fac. Recur. Mar. Univ. Antofagasta, 15: 1-10.

Avendaño, M. and M. Le Pennec. - 1997. Intraspecific variation in gametogenesis in two populations of the Chilean mollusc bivalve, Argopecten purpuratus (Lamarck). Aquac. Res., 28: $175-183$

Avendaño, M., M. Le Pennec and M. Cantillanez. - 2001. Anormalidades en larvas de Argopecten purpuratus (Lamarck, 1819) (Mollusca: Pectinidae), una causal de los problemas en la producción artificial de semilla. Estud. Oceanol., Fac. Recur. Mar. Univ. Antofagasta, 20: 32-42.

Avendaño, M., M. Cantillánez, M. Le Pennec, C. Lodeiros and L. Freites. - 2001. Cultivo de pectínidos Iberoamericanos en suspensión. In: A.N. Maeda-Martínez (ed.), Los Moluscos Pectínidos de Iberoamerica: Ciencia y Acuicultura, pp 193-211 Editorial Limusa, México.

Avendaño, M., M. Cantillánez, L. Rodríguez, O. Zuñiga, R. Escribano and M. Oliva. - 2004. Conservación y protección Reserva Marina La Rinconada Antofagasta-Chile. Informe Final Proyecto FNDR Cód. BIP N² 20127869-0. 215 pp. Univ. Antofagasta.

Avendaño, M., M. Cantillánez and J.B. Peña. - 2006. Effect of immersion time of cultch on spatfall of the scallop Argopecten purpuratus (Lamarck 1819) in the Marine Reserve at La Rinconada, Antofagasta, Chile. Aquacul. Int., 14:267-283.

Brand, A., J. Paul and J. Hoogester. - 1980. Spat settlement of scallops Chlamys opercularis (L) and Pecten maximus (L) on artificial collectors. J. Mar. Biol. Ass. UK., 60: 379-389.

Boucher, J. - 1985. Caractéristiques dynamiques du cycle vital de la coquille Saint-Jacques (Pecten maximus): hypotheses sur les stades critiques pour le recrutement. Rapp. P.- V. Réun. Cons. Int. Explor. Mer, K23, 10 pp.

Cantillánez, M. - 2000. Reproduction, vie larvaire et pré-recrutement du Pectinidae Argopecten purpuratus (Lamarck, 1819) 
dans la baie d'Antofagasta (Chili). Ph. D. thesis Univ. Brest. France.

Cantillánez, M., G. Thouzeau and M. Avendaño. - 2001. Reproductive cycle in Argopecten purpuratus during El Niño and la Niña conditions: a case study in the Rinconada Bay (Chile). 13 $3^{\text {th }}$ International Pectinid Workshop, 18-24 April 2001, Coquimbo, Chile. pp. 86-88.

Cantillánez, M., M. Avendaño, G. Thouzeau and M. Le Pennec.2005. Reproductive cycle of Argopecten purpuratus (bivalvia:Pectinidae) in la Rinconada marine reserve, (Antofagasta, Chile): response to environmental effects of El Niño and La Niña. Aquaculture, 246: 181-195.

Disalvo, L.H., E. Alarcon, E. Martínez and E. Uribe. - 1984. Progress in mass culture of Argopecten purpuratus with notes on its natural history. Rev. Chil. Hist. Nat., 57 : 33-45.

Escribano, R., L. Rodríguez and C. Irribarren. - 1995. Temporal variability of sea temperature in Bay of Antofagasta, northern Chile (1991-1995). Estud. Oceanol., Fac. Recur. Mar. Univ. Antofagasta, 14: 39-47.

Fegan, D. - 1983. Scallop spat collection in the Oban area in 1982. $4^{\text {th }}$ Inter. Pectinid Workshop, 10-13, May 1983, Aberdeen, Scotland, $20 \mathrm{pp}$

Gajardo, G., P. Coutteau, K. Curé, P. Sorgeloos and J.A. Beardmore. - 1996. Nutritional improvement of the commercial production of marine aquaculture species through application of innovative biotechniques. In: G. Gajardo and P. Coutteau (eds.), Improvement of the Commercial Production of Marine Aquaculture Species, pp. 7-12. Proceedings of a workshop on Fish and Mollusc Larviculture. Chile.

Gilliespie, M.J. - 1983. Results of recent pectid R and D carried out at MFU, Ardtoe. $4^{\text {th }}$ Int. Pectinid Workshop, 10-13, May 1983, Aberdeen, Scotland, 9 pp.

Guillen, O. - 1983. Condiciones Oceanográficas y sus fluctuaciones en el Pacífico Sur-oriental. In: G.D. Sharp and J. Csirke (eds.), Actas de la consulta de expertos para examinar cambios en la abundancia y composición por especies de recursos de peces neríticos, San José, Costa Rica, 1983. FAO Inf. Pesca, (291) 3: 607-658.

Gruffydd, L. D. and A. Beaumont. - 1972. A method for rearing Pecten maximus larvae in the laboratory. Mar. Biol., 15: 350-355.

Gruffydd, L., W. Lane and A. Beaumont. - 1975. The glands of the larval foot in Pecten maximus (L.), and possible homologues in other bivalves. J. Mar. Biol. Ass. UK., 55: 463-476.

Le Pennec, M. - 1978. Genèse de la coquille larvaire et postlarvaire chez divers Bivalves marins. Ph. D. thesis Univ. Brest, France.

Lodeiros, C., A. Maeda-Martínez, L. Freites, E. Uribe, D. LLuchCota and M.T. Sicard. - 2001. Ecofisiologia de pectínidos iberoamericanos. In: A. Maeda-Martínez (ed.), Los moluscos pectínidos de Iberoamérica: Ciencia y Acuicultura, pp. 77-88. Editorial Limusa, México.

MacDonald, P.D.M. and T.J. Pitcher. - 1979. Age-groups from size-frequency data: a versatile and efficient method of analysing distribution mixtures. J. Fish. Res. Board Can., 36: 987-1001.

Maeda-Martínez A., T. Reynoso-Granados, P. Monsalvo-Spencer, M. Sicard, J. Mazón-Suástegui, O. Hernández, E. Segovia and R. Morales. - 1997. Supension culture of catarina scallop Argopecten ventricosus (circularis) (Sowerby II, 1842), in Bahia Magdalena, Mexico, at different densities. Aquaculture, 158: 235-246.

Marín, V., L. Rodríguez, L. Vallejo, J. Fuenteseca and E. Oyarce.1993. Efectos de la surgencia costera sobre la productividad primaria primaveral de Bahía Mejillones del Sur (Antofagasta, Chile). Rev. Chil. Hist. Nat., 66: 479-491.

Mason, J. - 1983. Scallop and queen fisheries in the British Isles. 147 pp. Fishing News (Books) Ltd., England.

Minchin, D. - 1976. Pectinid settlement. 1 ${ }^{\text {st }}$ Scallop Workshop, 1116 May. 1976, Baltimore, Ireland (mimeo).

Naidu, K.S. and R. Scaplen. - 1979. Settlement and survival of giant scallop Placopecten magellanicus larvae, on enclosed polyethylene film collectors. In: T.V.R. Pillay and W.A. Dill (eds.), Advances in Aquaculture, pp. 379-381. Fishing news (Books) Ltd., England.

Narvarte, M.A. - 2001. Settlement of tehuelche scallop, Aequipecten tehuelchus D'Orb., larvae on artificial substrata in San Matías Gulf (Patagonia, Argentina). Aquaculture, 196: 55-65.

Narvarte, M.A., E. Felix-Pico and L. Ysla-Chee. - 2001 Asentamiento larvario de pectínidos, en colectores artificiales. In: A. Maeda-Martínez (ed.), Los moluscos pectínidos de Iberoamérica: Ciencia y Acuicultura, pp. 173-192. Editorial Limusa, México.

Paul, J. D. 1978.- Settlement and growth of scallops on collectors. $2^{\text {nd }}$ Int. Pectinid Workshop Brest France. 23 pp.

Rodríguez, L., V. Marín, M. Farias and E. Oyarce. - 1991. Identification of an upwelling zone by remote sensing and in situ measurements. Mejillones del Sur Bay (AntofagastaChile). Sci. Mar. 55(Suppl. 3): 467-473.

Román, G. and J. Cano. - 1987. Pectinid settlement on collectors in Malaga, S.E. Spain, in 1985. $6^{\text {th }}$ International Pectinid Workshop. 9-14 April 1987, Menai- Bridge, Wales, 32 pp.

Salaün, M. - 1994. La Larve de Pecten maximus, genese et nutrition. Ph. D. thesis Univ. de Brest, France.

Sicard, M.T., A.N. Maeda-Martínez, P. Ormart, T. ReinosoGranados and L. Carvalho. - 1999. Optimun temperature for growth in the catarina scallop (Argopecten ventricosus-circularis, Sowerby II, 1842). J. Shellfish Res., 18: 385-392.

Slater, J. - 1980. Prediction of the time of peak settlement of the scallop, Pecten maximus by pectinid larval monitoring. $3^{\text {rd }}$ International Pectinids Workshop. 13-16 May 1980, Port Erin, Isle of Man, $32 \mathrm{pp}$.

Slater, J. - 2005. Spawning of King scallops, Pecten maximus (L.) in Mulroy Bay and the relationship with spatfall intensity. $J$. Shellfish Res., 24: 951-958.

Stotz, W.B. and J. Mendo. - 2001. Pesquería, repoblamiento y manejo de bancos naturales de pectínidos en Iberoamérica: su interacción con la acuicultura. In: A.N. Maeda-Martínez (ed.), Los Moluscos Pectínidos de Iberoamerica: Ciencia y Acuicultura, pp. 357-374. Editorial Limusa, México.

Thouzeau, G. - 1989. Déterminisme du pré-recrutement de Pecten maximus (L.) en baie de Saint-Brieuc. Ph. D. thesis, Univ. Brest, France.

Thouzeau, G. - 1991a. Experimental collection of postlarvae of Pecten maximus (L.) and other benthic macrofaunal species in the Bay of Saint-Brieuc, France. I Settlement patterns and biotic interaction among the species collected. J. Exp. Mar. Biol. Ecol., 148: 159-179.

Thouzeau, G. - 1991b. Experimental collection of postlarvae of Pecten maximus (L.) and other benthic macrofaunal species in the Bay of Saint-Brieuc, France. II Reproduction patterns and postlarval growth of five mollusk species Settlement patterns and biotic interaction among the species collected. J. Exp. Mar. Biol. Ecol., 148: 181-200.

Thouzeau, G. - 1991c. Déterminisme du pré-recrutement de Pecten maximus (L.) en baie de Saint-Brieuc: processus régulateurs de l'abondance, de la survie et de la croissance des post-larves et juvéniles. Aquat. Living Resour., 4: 77-99.

Thouzeau, G. - 1995. Aspects de la dynamique spatio-temporelle du pré-recrutement de Pecten maximus L., en baie de SaintBrieuc. ICES mar. Sci. Symp., 199: 31-39.

Ventilla, R.F. - 1982. The scallop Industry in Japan. Adv. Mar. Biol., 20: 310-380.

Wallace, J.C. and T.G. Reinsnes. - 1984. Growth variation with age and water depth in the Iceland scallop (Chlamys islandica, Pectinidae). Aquaculture, 41: 141-146.

Wallace, J.C. and T.G. Reinsnes. - 1985. The significance of various environmental parameters for growth of the Iceland scallop Chlamys islandica (Pectinidae), in hanging culture. Aquaculture, 44: 229-242.

Wilson, J. - 1987. Reproduction of Pecten maximus (L) in Kilkieran bay, Co. Galway, Ireland. $6^{\text {th }}$ International Pectinid Workshop, Menai-Bridge.

Yamamoto, G. - 1964. Studies on the propagations of the scallop Patinopecten yessoensis (Jay) in Mutsu bay. Fish. Res. Bd. Canada. Trans. Series, 1054: 68 pp.

Scient. ed.: C. Froglia.

Received June 14, 2006. Accepted November 14, 2006.

Published online March 5, 2007. 
